Article

\title{
Biocompatibility and Biological Efficiency of Inorganic Calcium Filled Bacterial Cellulose Based Hydrogel Scaffolds for Bone Bioengineering
}

\author{
Probal Basu ${ }^{1}\left(\mathbb{D}\right.$, Nabanita Saha ${ }^{1, *(\mathbb{D})}$, Radostina Alexandrova ${ }^{2}$, Boyka Andonova-Lilova ${ }^{2}$, \\ Milena Georgieva ${ }^{3}{ }^{D}$, George Miloshev ${ }^{3}$ and Petr Saha ${ }^{1}$ \\ 1 Centre of Polymer Systems, University Institute, Tomas Bata University in Zlin, Trida Tomase Bati 5678, \\ 76001 Zlín, Czech Republic; probal@utb.cz (P.B.); saha@utb.cz (P.S.) \\ 2 Institute of Experimental Morphology, Pathology and Anthropology with Museum, \\ Bulgarian Academy of Sciences, 1113 Sofia, Bulgaria; rialexandrova@hotmail.com (R.A.); \\ boika_andonova@hotmail.com (B.A.-L.) \\ 3 Laboratory of Molecular Genetics, Institute of Molecular Biology "Acad. R. Tsanev", \\ Bulgarian Academy of Sciences, 1113 Sofia, Bulgaria; milenageorgy@gmail.com (M.G.); \\ miloshev@bio21.bas.bg (G.M.) \\ * Correspondence: nabanita@utb.cz; Tel.: +420-57603-8156
}

Received: 19 October 2018; Accepted: 27 November 2018; Published: 11 December 2018

\begin{abstract}
The principal focus of this work is the in-depth analysis of the biological efficiency of inorganic calcium-filled bacterial cellulose (BC) based hydrogel scaffolds for their future use in bone tissue engineering/bioengineering. Inorganic calcium was filled in the form of calcium phosphate ( $\beta$-tri calcium phosphate $(\beta-\mathrm{TCP})$ and hydroxyapatite (HA)) and calcium carbonate $\left(\mathrm{CaCO}_{3}\right)$. The additional calcium, $\mathrm{CaCO}_{3}$ was incorporated following in vitro bio-mineralization. Cell viability study was performed with the extracts of $\mathrm{BC}$ based hydrogel scaffolds: BC-PVP, BC-CMC; BC-PVP- $\beta-\mathrm{TCP} / \mathrm{HA}, \mathrm{BC}-\mathrm{CMC}-\beta-\mathrm{TCP} / \mathrm{HA}$ and BC-PVP- $\beta-\mathrm{TCP} / \mathrm{HA}-\mathrm{CaCO}_{3}$, $\mathrm{BC}-\mathrm{CMC}-\beta-\mathrm{TCP} / \mathrm{HA}-\mathrm{CaCO}_{3}$; respectively. The biocompatibility study was performed with two different cell lines, i.e., human fibroblasts, Lep-3 and mouse bone explant cells. Each hydrogel scaffold has facilitated notable growth and proliferation in presence of these two cell types. Nevertheless, the percentage of DNA strand breaks was higher when cells were treated with BC-CMC based scaffolds i.e., BC-CMC- $\beta-\mathrm{TCP} / \mathrm{HA}$ and $\mathrm{BC}-\mathrm{CMC}-\beta-\mathrm{TCP} / \mathrm{HA}-\mathrm{CaCO}_{3}$. On the other hand, the apoptosis of human fibroblasts, Lep-3 was insignificant in BC-PVP- $\beta-T C P / H A$. The scanning electron microscopy confirmed the efficient adhesion and growth of Lep-3 cells throughout the surface of BC-PVP and BC-PVP- $\beta$-TCP/HA. Hence, among all inorganic calcium filled hydrogel scaffolds, 'BC-PVP- $\beta$-TCP $/ \mathrm{HA}^{\prime}$ was recommended as an efficient tissue engineering scaffold which could facilitate the musculoskeletal (i.e., bone tissue) engineering/bioengineering.
\end{abstract}

Keywords: bacterial cellulose; in vitro bio-mineralization; bone tissue engineering; biocompatibility; apoptosis; DNA damage

\section{Introduction}

Bone is an important part of the animal musculoskeletal system. The structural framework of an animal is preserved by the bones through modelling and remodeling events [1,2]. Extensive research indicated that bone related disorders like osteoporosis affect 75 million individuals throughout Europe, USA and Japan. In addition, many studies also showed that osteoporosis causes more than 8.9 million fractures worldwide annually; with a condition where an osteoporotic fracture occurs in every $3 \mathrm{~s}$ [3]. The possible treatment methods for this comprise the use of either auto/allografts or 
ceramic coated/inert metallic implants, which in many cases are far too expensive for application [4]. In this context, the hydrogel based bioactive scaffold can become a notable approach in bone tissue engineering/bone bioengineering; due to its osteo-conduction and osteo-induction properties, notable mechanical property and further its cost-effective production attributes [5].

The hydrogel is a three dimensional polymeric network structure which can retain significant amount of water [6-8]. The hydrogel based bioactive scaffolds have the necessary attributes to become an efficient extra cellular matrix (ECM) that has the potential to execute the primary functions of the tissue engineering scaffolds like cell adhesion, stimulation for cell proliferation and others $[9,10]$. Different polymers, polymer-composite scaffolds are often utilized in the design of an efficient scaffold material. Additionally, a variety of synthetic polymers like poly(lactic-co-glycolic) acid (PLGA), poly(glycolic acid) (PGA) poly(caprolactone) (PCL) and natural polymers like collagen, hyaluronic acid have also been used in the fabrication of tissue engineering scaffold [11-16].

Research showed that bacterial cellulose (BC) based hydrogel scaffolds could also become a potential biomaterial for tissue regeneration application [17]. BC is a biocompatible biopolymer [18] and has high crystallinity, ultra-fine network structure and high water absorption capability $[19,20]$. These significant structural and functional properties of BC increase its importance in musculosketal/tissue engineering/bone bioengineering applications.

The inorganic phase of the bone tissue is composed majorly of calcium mineral [21]. However, recent research data reported that the extracellular calcium had a significant role in cellular growth and development [22]. Bone cells are comprised of different calcium ion channels and extracellular calcium receptors that receive the signals from the extracellular $\mathrm{Ca}^{2+}[23,24]$, which in turn generates specific genetic responses related to cell growth and proliferation [25]. Studies indicated that the biocompatibility and the mechanical properties of the tissue engineering scaffolds can be modified and improved by addition of calcium phosphate [26,27]. Bioactive calcium phosphate fillers like $\beta$-tri-calcium phosphate ( $\beta$-TCP), octa-calcium phosphate (OCP) and hydroxyapatite (HA) improve the osteo-conduction and osteo-induction properties of the biomaterial $[17,28]$. On the other hand, inorganic calcium can also be incorporated in the tissue engineering scaffold through organic-inorganic hybridization. A variety of methods of the organic-inorganic hybridization (i.e., solvent casting/particle leaching, scaffold coating, etc.) have been developed for the inclusion of bioactive $\mathrm{CaCO}_{3}$ within the polymer matrix in order to obtain improvement in the structural and functional properties of the scaffold [29].

Polyvinylpyrrolidone (PVP) is a synthetic polymer which has significant biocompatibility. Several studies indicated that the application of PVP is not so widespread due to its poor mechanical properties and low swelling capacity [30]. However, the properties of PVP can be improved when it is blended with polysaccharides. On the other hand, carboxymethyl cellulose (CMC) is the cellulose derivative which has also significant utilization in cosmetology and as a water retention agent. Additionally, CMC has notable biocompatibility [30,31]. The blending of the above mentioned polymers, PVP-CMC hydrogel scaffold; has been previously successfully prepared in our laboratory. The biological efficiency of PVP-CMC scaffold has also been found suggestive [30-32]. BC is a natural polymer which also has significant biocompatibility and notable mechanical properties. Recent data indicated that a variety of composite materials prepared with $\mathrm{BC}$ such as $\mathrm{BC} / \mathrm{Chitosan}, \mathrm{BC} /$ collagen were used in biomedical applications; especially in tissue engineering/bone bioengineering [33,34]. The hydrogel scaffolds prepared from the natural polymers like BC and synthetic polymers PVP and CMC have also been reported in our previous work [19]. Albeit all the above-mentioned hydrogel scaffolds have the necessary material characteristics (like mechanical, rheological properties) for tissue engineering application; however, in order to develop a more specific bone tissue engineering scaffold, inorganic calcium (in the form of calcium phosphate or/and $\mathrm{CaCO}_{3}$ ) filled $\mathrm{BC}$ based hydrogel scaffolds were developed. In the present work, the focus is given on the in vitro characterization of the novel inorganic calcium filled BC based hydrogel scaffolds through evaluation of their biocompatibility and biological efficiency in a series of cell-based assays. 


\section{Results}

The novel inorganic calcium filled scaffolds "BC-PVP- $\beta$-TCP/HA", "BC-CMC- $\beta$-TCP/HA", "BC-PVP- $\beta-\mathrm{TCP} / \mathrm{HA}-\mathrm{CaCO}_{3}$ ", and "BC-CMC- $\beta-\mathrm{TCP} / \mathrm{HA}-\mathrm{CaCO}_{3}$ " were prepared and their biocompatibility and biological efficiency (in a series of cell based assays) were evaluated in order to recommend for its application for bone tissue engineering/bioengineering, where, the "BC-PVP" and "BC-CMC" scaffolds were considered as a control set of scaffolds. To analyze the biological efficiency of these scaffolds, the following investigations were performed and discussed below.

\subsection{Cell Viability and Biocompatibility Study}

Cell viability studies have been performed through MTT(3-(4,5-Dimethylthiazol-2-yl)-2,5diphenyltetrazolium bromide) test in indirect (IDE) and direct experiments (DE) using human embryonic fibroblasts (Lep-3) and mouse bone explant cells (BEC), and are summarized in Figure 1.

It can be seen from Figure 1 that the detected cytotoxicity of the calcium filled scaffolds was low in the studied cell cultures, when determined in IDEs and incubated in 3, 5 and 7 days' extract culture medium. In contrast, it is clearly visible that the existence of the viable Lep-3 and BEC cells has been specially affected by the presence of $\mathrm{BC}-\mathrm{CMC}-\beta-\mathrm{TCP} / \mathrm{HA}-\mathrm{CaCO}_{3}$ and decreased in number after 5 days. However, both the cells were affected more or less in the presence of all the scaffolds after 7 days except "BC-PVP- $\beta-\mathrm{TCP} / \mathrm{HA}^{\prime}$ in DE and in presence of BEC. In general, "BC-CMC- $\beta-\mathrm{TCP} / \mathrm{HA}-\mathrm{CaCO}_{3}$ " exhibited the highest cytotoxic activity in DEs for both human and mouse cells (i.e., Lep-3 and BEC). 

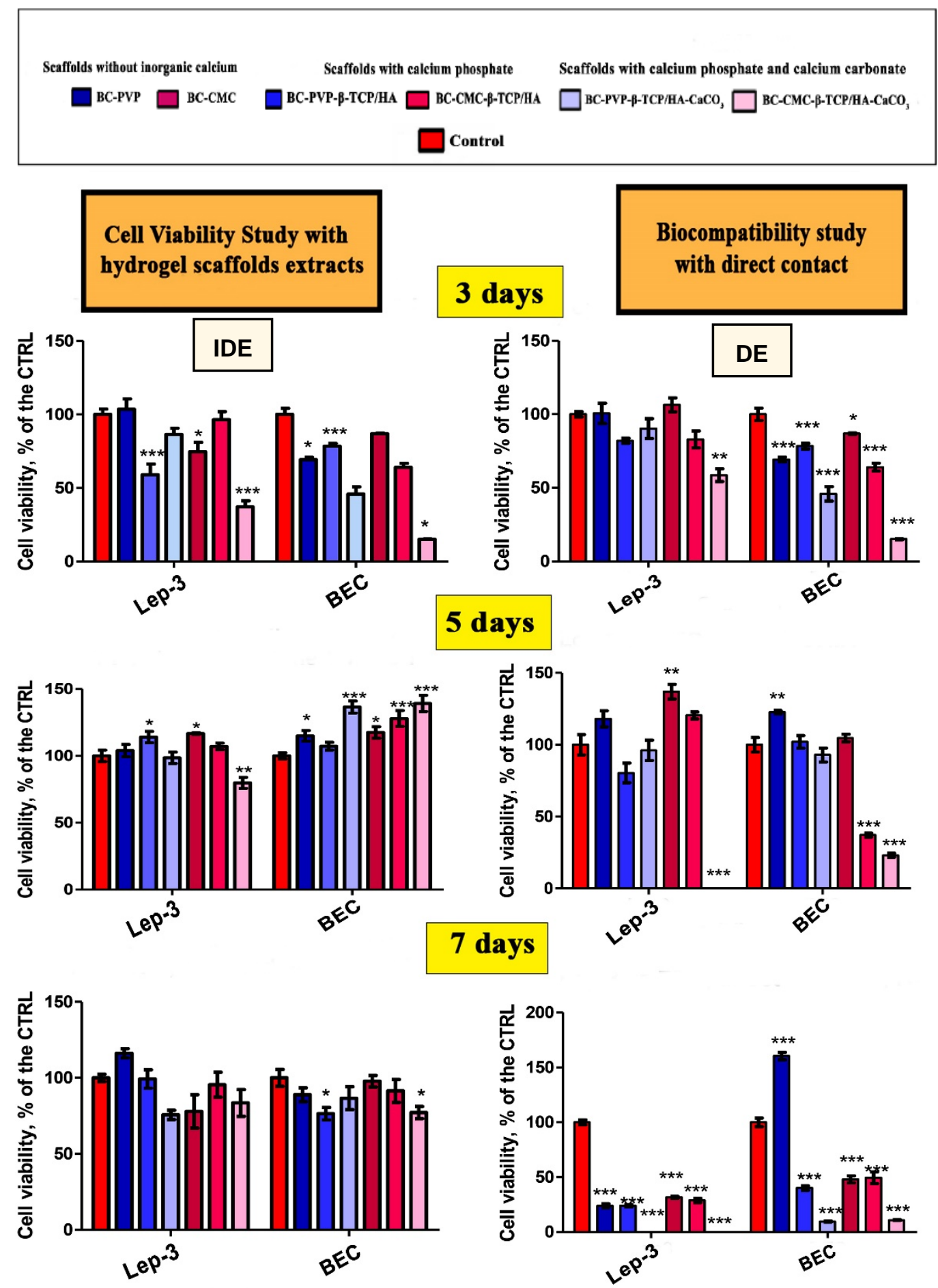

Figure 1. Human fibroblast, Lep-3 and mouse bone explant cells (BEC) cellular viability (proliferation profiles) after incubation with six different BC based hydrogel scaffolds (scaffolds without inorganic calcium, scaffolds with calcium phosphate, scaffolds with calcium phosphate and $\mathrm{CaCO}_{3}$ ); established by indirect (IDE) and direct experiments (DE). ${ }^{*} p<0.05 ;{ }^{* *} p<0.005 ;{ }^{* *} p<0.0001$ as compared to the control.

\subsection{Genotoxic Potential of the Studied BC Based Inorganic Calcium Filled Hydrogel Scaffolds}

The genotoxic potential of the studied $\mathrm{BC}$ based inorganic calcium filled hydrogel scaffolds was determined by the method of Comet Assay in alkaline conditions in order to detect all kinds of DNA breaks; in which the tested scaffolds can potentially induce genotoxic effect (i.e., DNA breaks) in 
the cells. Lep-3 cells were used as the model cellular system in this study. The Comet Assay data quantitation included calculation of the percentage of comets, i.e., cells with damaged DNA in all tested probes and results are displayed on Figure 2. It can be seen that, the higher percentage of comets (cells with damaged DNA) was observed in Lep-3 cells grown in 3 days' extract culture medium from BC-CMC- $\beta$-TCP/HA and BC-CMC- $\beta-\mathrm{TCP} / \mathrm{HA}-\mathrm{CaCO}_{3}$; where more than $60 \%$ of all observed cells per probe were with damaged DNA. On the other hand, more than $60 \%$ of cells incubated with BC-PVP- $\beta$-TCP $/ \mathrm{HA}$ and BC-PVP- $\beta-\mathrm{TCP} / \mathrm{HA}-\mathrm{CaCO}_{3}$ were found with native, i.e., untouched/unaffected DNA, in comparison to the control and cells with BC-CMC- $\beta-\mathrm{TCP} / \mathrm{HA}$ and BC-CMC- $\beta$-TCP $/ \mathrm{HA}-\mathrm{CaCO}_{3}$ scaffolds.

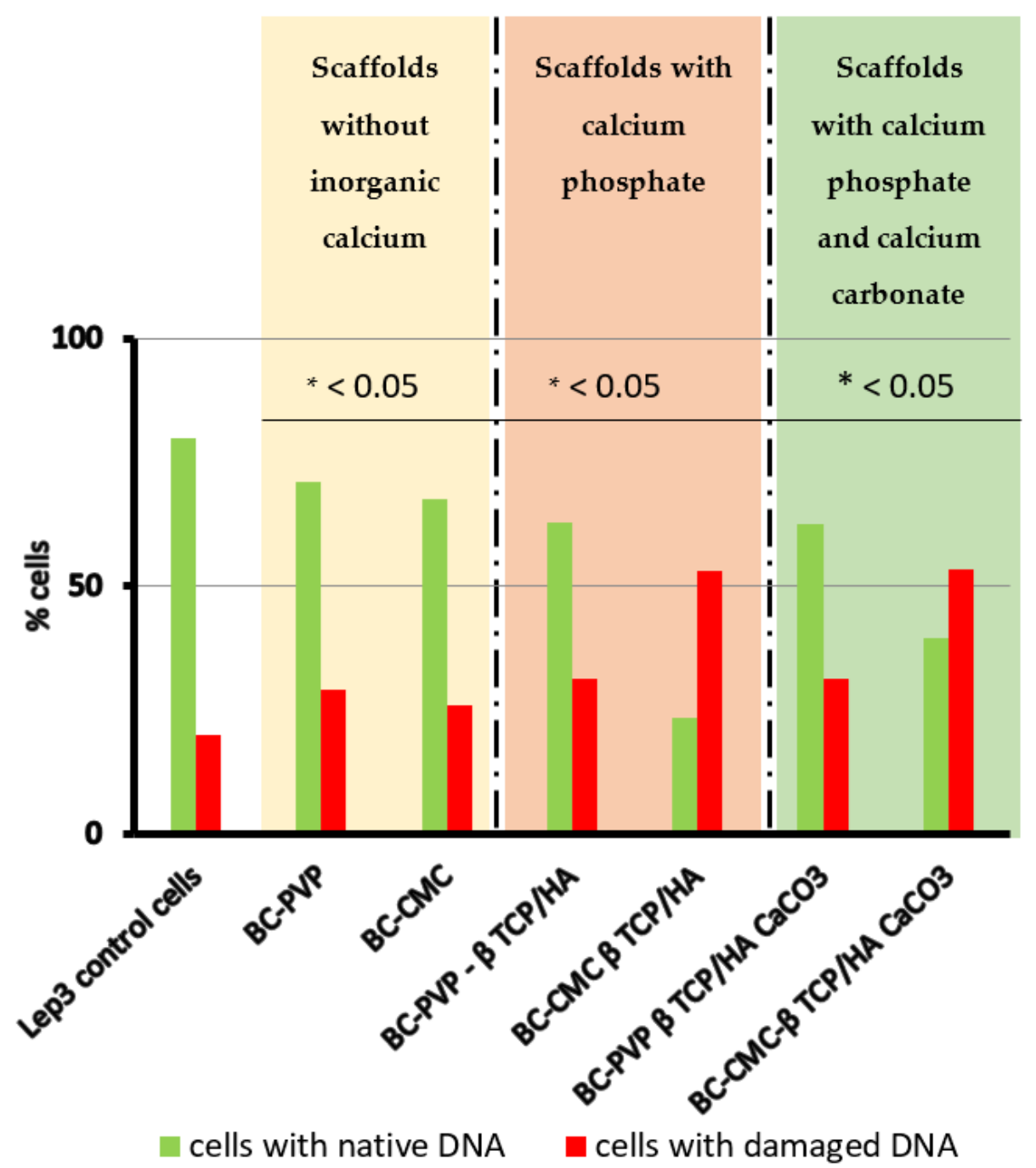

Figure 2. Genotoxicity testing of the studied biocompatible scaffolds was done by the method of Comet Assay in Lep-3 cells in the presence of extracts of all six BC based hydrogel scaffolds. Data quantitation proceeded with estimation of the percentage of comets by assuming the total number of objects per probe ( $n=1000$ ) as $100 \%$ and the percentage of comets, i.e., cells with damaged DNA was estimated and represented as a graph. Student $t$ test was performed and the estimated $p$ values for all probes in comparison to the control were statistically significant $p<0.05$.

\subsection{Study on Apoptosis/Necrosis}

In order to elucidate the mechanisms of the biological action of the tested scaffolds on the studied cellular model systems and to understand the reasons for the detected genotoxic potential of those with calcium phosphate and carbonate functionalization, i.e., BC-CMC- $\beta-\mathrm{TCP} / \mathrm{HA}$ and 
BC-CMC- $\beta$-TCP $/ \mathrm{HA}-\mathrm{CaCO}_{3}$ (already detected with the Comet Assay Figure 2), FACS analysis (fluorescence activated cell sorting) with Annexin V-FITC kit performed for evaluation of the percentage of cells undergoing apoptosis and necrosis when layered onto all studied scaffolds. The percentage of apoptotic and necrotic cells together with the percentage of live cells was estimated by software data quantitation. Further on the ratio among cells in apoptosis and necrosis and alive cells was done and is displayed in procedure data values (PDU) on Figure 3. The last represents the ratio between apoptotic and necrotic cells in the probes versus these percentages in the controls (Lep-3 control cells). The blue bars on Figure 3 represent the ratio between the percentages of apoptotic cells in the probes versus the control, while the red bars represent the ratio between the percentages of necrotic cells in the tested probes versus the necrotic cells in the control. As it is easily seen on Figure 3 an increased number (around $40 \%$ ) of apoptotic cells was detected in the probes of human Lep-3 cells grown in 3 days' extract culture medium in presence of BC-CMC- $\beta-\mathrm{TCP} / \mathrm{HA}, \mathrm{BC}-\mathrm{PVP}-\beta-\mathrm{TCP} / \mathrm{HA}-\mathrm{CaCO}_{3}$ and $\mathrm{BC}-\mathrm{CMC}-\beta-\mathrm{TCP} / \mathrm{HA}-\mathrm{CaCO}_{3}$. Interestingly, the trend with the observed increase of apoptosis between BC-PVP and BC-PVP- $\beta$-TCP/HA was similar but when compared to BC-CMC- $\beta$-TCP $/ \mathrm{HA}$, BC-PVP- $\beta-\mathrm{TCP} / \mathrm{HA}-\mathrm{CaCO}_{3}$ and $\mathrm{BC}-\mathrm{CMC}-\beta-\mathrm{TCP} / \mathrm{HA}-\mathrm{CaCO}_{3}$ it was not so-well pronounced as previously expected.

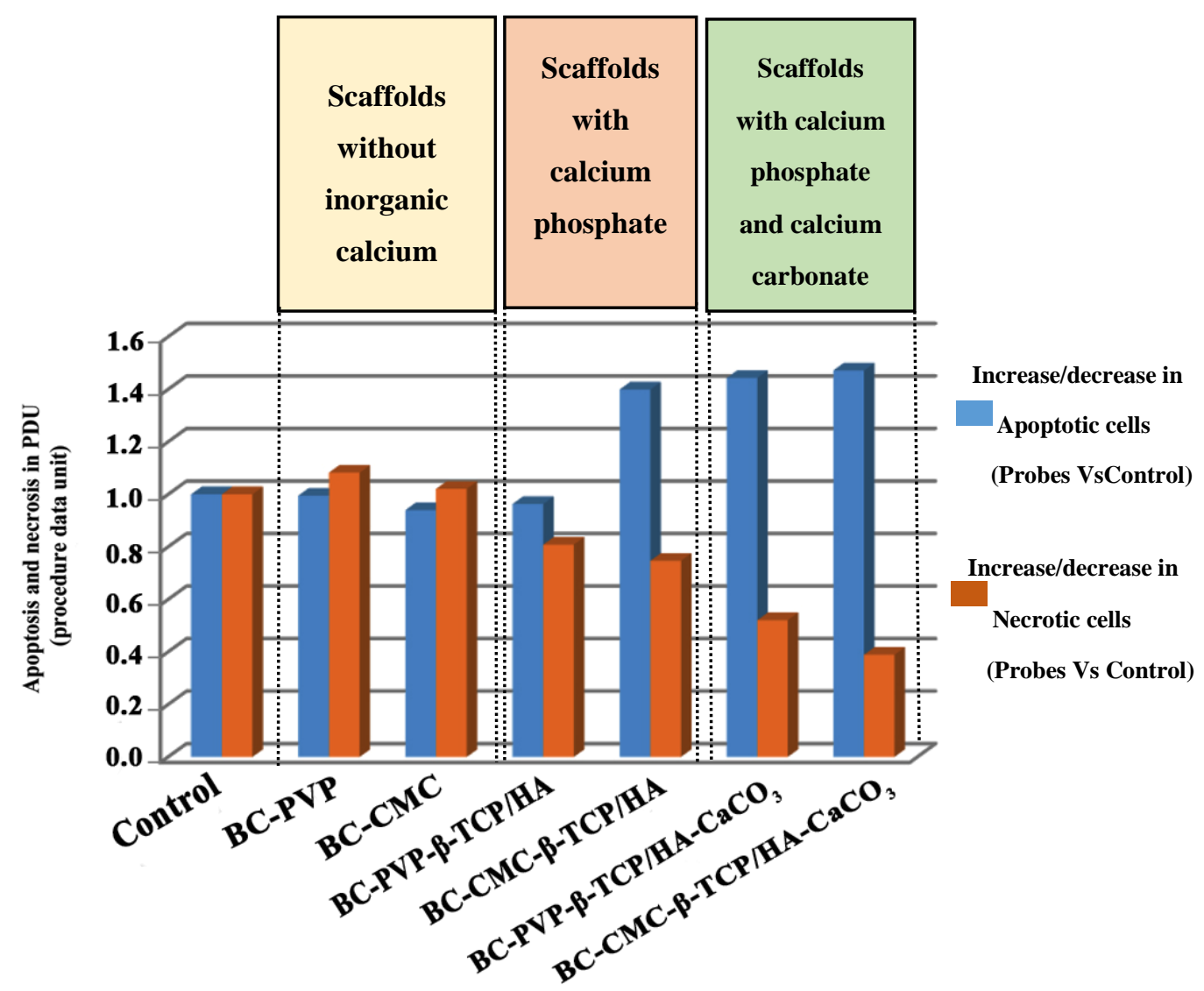

Figure 3. Discrimination between apoptotic and necrotic types of cell death induced by the tested scaffolds in Lep-3 cells. FACS analysis with Annexin V-FITC kit for apoptosis/necrosis detection was applied on Lep-3 cells cultivated in presence of six studied scaffolds. Data quantitation included estimation of the percentage of cells undergoing apoptosis and necrosis and the ratio between these percentages in comparison to the control cells is given in PDU (procedure data units).

Noteworthy, the results from the FACS analysis for discrimination between apoptosis and necrosis are in correspondence with the results from the alkaline Comet Assay. The detected genotoxic potential of BC-CMC- $\beta-\mathrm{TCP} / \mathrm{HA}$ and BC-CMC- $\beta-\mathrm{TCP} / \mathrm{HA}-\mathrm{CaCO}_{3}$ is also reflected in the experiments for studying of the mechanisms for the induction of different types of cell death. In the cases when 
cells were cultivated in the presence of these types of scaffolds (i.e., BC-CMC- $\beta$-TCP/HA and BC-CMC- $\beta$-TCP $/ \mathrm{HA}-\mathrm{CaCO}_{3}$ ), the higher levels of apoptosis were seen. It could be a result from the possible genotoxic effect of these substances/scaffolds.

\subsection{SEM Analysis}

The SEM analysis of hydrogel scaffolds-Lep-3 cell interaction is depicted in Figure 4 . The analysis was performed with BC-PVP and BC-PVP- $\beta-\mathrm{TCP} / \mathrm{HA}$, as these materials showed better cyto-compatibility in direct (DE) and indirect experiments (IDE). The presence of Lep-3 cells including groups of 2-3 cells was observed on the surface of both materials (Figure 4). The adhered Lep-3 cells on the surface of BC-PVP- $\beta$-TCP/HA can be seen notably.

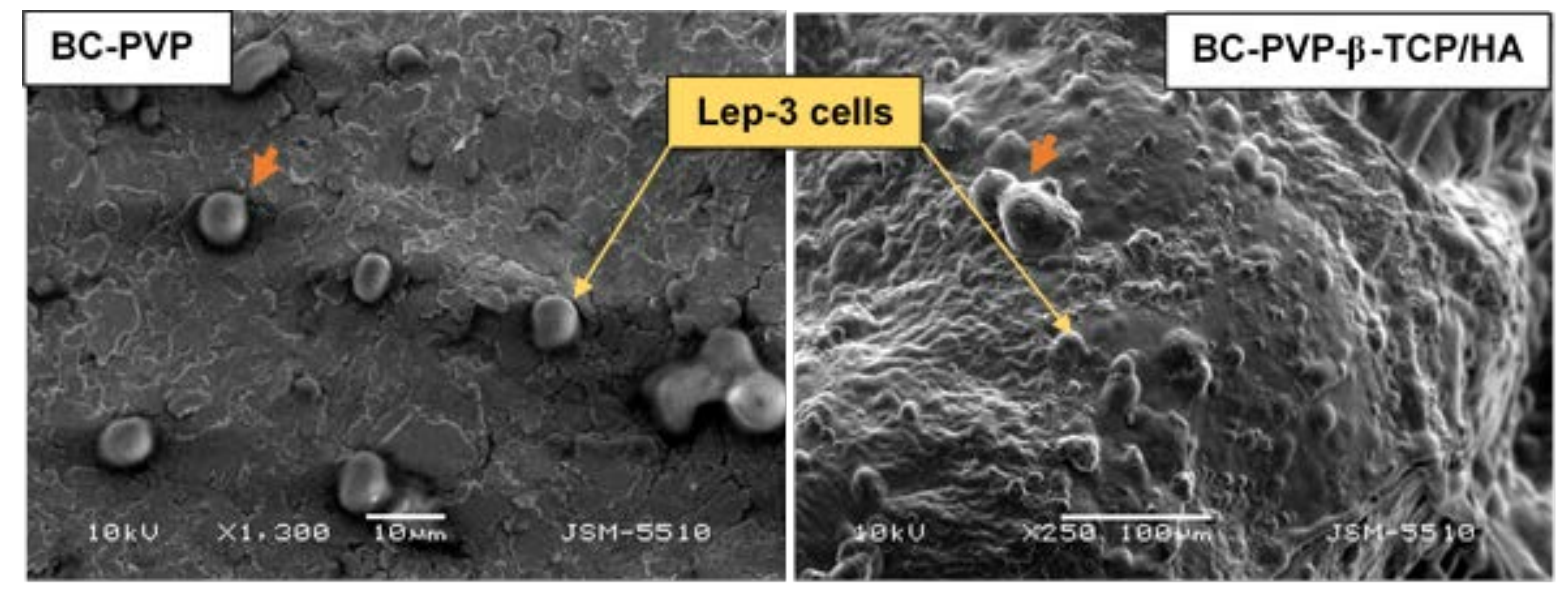

Figure 4. SEM images of Lep-3 cells grown on BC based hydrogel (BC-PVP and BC-PVP- $\beta$-TCP/HA).

The orange colored arrow indicates developing projections.

\section{Discussion}

Generally, the significant properties of scaffold materials involve efficient architecture, cyto-compatibility and notable mechanical property. Recently many different scaffold materials have been developed with a variety of synthetic and natural polymers [11]. However, the application of natural polymers like bacterial cellulose (BC) for tissue regeneration is also very promising [35]. In this study, BC was used with different biocompatible polymers like PVP, CMC, etc. Calcium phosphate (in the form of $\beta$-TCP/HA) was added within the polymer matrix. Moreover, the calcium phosphate filled scaffolds were further in vitro biomineralized to develop calcium phosphate and calcium carbonate filled biomineralized hydrogel scaffold. The applied cell based assays for studying of their biological properties demonstrated the promising cyto-compatibility.

Calcium phosphate like $\beta$-TCP and HA can facilitate osteo-conduction, which ultimately results in high cell viability [36]. In the cell viability study with sample extract in IDE, the BEC viability was significant for BC-PVP- $\beta$-TCP/HA-CaCO 3 after 5 days of incubation. Additionally, there was a trend of increase also seen in BEC viability with BC-CMC and calcium phosphate and calcium carbonate filled hydrogel scaffolds after 5 day of incubation. Moreover, until the 7 day of incubation, cell viability for Lep-3 and BEC was still significant for all the BC based hydrogels. Other authors studies indicated that $\mathrm{CaCO}_{3}$ facilitates cell viability for fibroblasts [37]. In this context, it is relevant to mention that; the Lep-3 cells are embryonic fibroblast cells [38] and not at all are specified to elicit prompt response in the presence of notable calcium content in the surrounding environment. Thus, through acclimatization with the significant inorganic calcium environment, the cells exhibit high viability with the gradually increasing incubation period from 72 to $168 \mathrm{~h}$. In regard to the biocompatibility study in the direct contact (DE) with the scaffolds, the BEC and Lep-3 cells initially acclimatized with the chemical and physical environment that has been provided by the scaffold sections and thus showed cell growth and viability after 3 days of incubation. Then gradually the higher cell viability started to be visible 
after 5 days of incubation. Interestingly, after 7 days of incubation, the Lep-3 and BEC cell viability decreased in comparison to cell viability after 3 days and 5 days of incubation. In any case, the BEC viability was found higher for BC-PVP after 7 days of incubation.

Porosity is an important factor for bone cell growth and proliferation [39]. Thus, the significant porous structures of BC-PVP scaffold section might provide the necessary environment for BEC growth efficiently after 7 days of incubation. On the other hand, research indicated that high levels of $\mathrm{Ca}^{2+}$ can negatively influence DNA repair ability to the cells [40] and thereby can cause less cell viability. Interestingly, after 7 days of incubation, the BEC and Lep-3 cell viability was significantly fewer when incubation performed with in vitro biomineralized samples. Lep-3 cells were unable to get any proliferation stimulation in contact $(\mathrm{DE})$ with the in vitro biomineralized samples (BC-PVP- $\beta$-TCP $/ \mathrm{HA}-\mathrm{CaCO}_{3}, \mathrm{BC}-\mathrm{CMC}-\beta-\mathrm{TCP} / \mathrm{HA}-\mathrm{CaCO}_{3}$ ) after 7 days of incubation. This indicates that in vitro biomineralized hydrogels can only provide an initial stimulatory signals to Lep-3 cells. As Lep-3 cells are sensitive human embryonic cells (but not stem cells), the initial high concentration of calcium in the cell culture environment causes them to significantly proliferate up to 3 days of incubation in the presence of all six hydrogel scaffolds, while no proliferation was observed after 5 days of incubation during direct experiments (DE). However, the Lep- 3 cell viability after 5 days of incubation with BC-PVP- $\beta-\mathrm{TCP} / \mathrm{HA}-\mathrm{CaCO}_{3}$ very possibly resulted from the combined positive effect provided by the polymers (BC and PVP) and the inorganic calcium content. Finally, the high calcium content most probably inhibits the subsequent proliferation of both human and mouse cells after 7 days of incubation.

The results from the method of comet assay signified the occurrence of DNA damage in the cells when Lep-3 cells were used in the study to evaluate the genotoxic effect of hydrogel scaffolds. Albeit, $\mathrm{BC}$ and $\mathrm{CMC}$ have been proved to be biocompatible polymers, together with calcium phosphate in BC-CMC- $\beta$-TCP/HA hydrogel scaffold, they might develop a cellular burden by possible induction of considerable number of DNA breaks. Earlier reports showed that several polymers and ceramics can indeed cause oxidative stress $[41,42]$ in the cells, which ultimately resulted in DNA strand breaks [43]. The possible interaction of BC, CMC and calcium phosphate (for BC-CMC- $\beta$-TCP/HA hydrogel scaffold) might develop oxidative stress to the cells which could finally result in high percentage of comets (cells with damaged DNA). Moreover, research indicated that the elevation of the calcium ion $\left(\mathrm{Ca}^{2+}\right)$ concentration can also influence DNA repair ability of the cells [40]. This phenomenon is evident of Figure 1, where the percentage of live cells was found less for the BC-CMC- $\beta$-TCP $/ \mathrm{HA}-\mathrm{CaCO}_{3}$ hydrogel scaffold. The degree of DNA damage might be greater than the DNA repair ability for BC-CMC- $\beta-\mathrm{TCP} / \mathrm{HA}-\mathrm{CaCO}_{3}$. On the other hand, the notable percentage of live cells for BC-PVP- $\beta$-TCP $/ \mathrm{HA}$ and BC-PVP- $\beta-\mathrm{TCP} / \mathrm{HA}-\mathrm{CaCO}_{3}$ indicated the introduction of less DNA damage into the fibroblast cells (Lep-3).

Regarding apoptosis/necrosis study, the necrosis level was found gradually decreasing compared to apoptosis (Necrosis: BC-PVP > BC-CMC > BC-PVP- $\beta$-TCP $/ \mathrm{HA}>$ BC-CMC- $\beta$-TCP $/ \mathrm{HA}>$ BC-PVP- $\left.\beta-\mathrm{TCP} / \mathrm{HA}-\mathrm{CaCO}_{3}>\mathrm{BC}-\mathrm{CMC}-\beta-\mathrm{TCP} / \mathrm{HA}-\mathrm{CaCO}_{3}\right)$. Other researchers demonstrated that, an elevated extracellular $\mathrm{Ca}^{2+}$ can cause the production of reactive oxygen species (ROS) in cellular mitochondria, which thereby induces the destruction of the mitochondrial membrane that finally initiates the apoptosis through the release of cytochrome $\mathrm{C}$ into the cytoplasm [44]. Possibly, the in vitro biomineralized $\mathrm{CaCO}_{3}$ filled samples (BC-PVP- $\beta-\mathrm{TCP} / \mathrm{HA}-\mathrm{CaCO}_{3}, \mathrm{BC}-\mathrm{CMC}-\beta-\mathrm{TCP} / \mathrm{HA}-\mathrm{CaCO}_{3}$ ), creates high $\mathrm{Ca}^{2+}$ environment around the Lep-3 cell population which might also increase the intracellular $\mathrm{Ca}^{2+}$ levels which could have resulted in apoptosis. Earlier research indicated that caspase-8; a cysteine aspartate protease involved in apoptosis, has a specific role in suppression of necrosis and facilitation of apoptosis [45]. Our studies show that, the apoptosis level is also seen increasing following incubation time with the calcium phosphate filled scaffolds and with the in vitro biomineralized $\mathrm{CaCO}_{3}$ filled hydrogel scaffolds. The possible formation of caspase- 8 in some population of the cells might be responsible for the significant shift from necrosis to apoptosis in all biomineralized $\mathrm{CaCO}_{3}$ filled hydrogel scaffolds. Interestingly, the elevated level of apoptosis 
compared to necrosis can also be seen in BC-CMC- $\beta$-TCP/HA compared to BC-PVP- $\beta$-TCP $/ \mathrm{HA}$ hydrogel scaffold. This might be associated with the combinatorial effect of polymers (BC, CMC) and calcium phosphate ( $\beta-\mathrm{TCP} / \mathrm{HA})$. In addition, the cell viability, rather than apoptotic/necrotic cell death is also found higher in BC-PVP- $\beta$-TCP/HA, compared to BC-CMC- $\beta$-TCP/HA and BC-CMC- $\beta$-TCP $/ \mathrm{HA}-\mathrm{CaCO}_{3}$. Furthermore, the apoptotic/necrotic cell death is also found 10 folds less for BC-CMC than BC-PVP.

Scientific data revealed that different materials contains various surface characteristics like the surface topography, wettability, roughness, softness which notably influence a variety of cell behavior like cellular adhesion, growth, differentiation $[46,47]$. BC-PVP and BC-PVP- $\beta$-TCP/HA hydrogel scaffolds contain the necessary attributes (mechanical and microstructural properties) [48] which facilitate efficient Lep-3 fibroblast cell adhesion on the surface of the hydrogel scaffolds. Additionally, the homogenous cell adhesion also signifies the efficient adsorption of cell adhesion proteins to the surface of the hydrogel scaffolds. This focal adhesion of cells on the surface of these hydrogel scaffolds will further facilitate the cell proliferation and growth events which ultimately elaborate the event of tissue regeneration [45].

\section{Materials and Methods}

\subsection{Materials}

Polyvinylpyrrolidone K30 (PVP K30; molecular weight: 40,000), Polyethylene glycol 3000 (PEG; average molecular weight: 2700-3300), Agar, $\beta$-tri calcium phosphate ( $\beta$-TCP; molecular weight: $310.18 \mathrm{~g} / \mathrm{mol}$ ) were supplied by Fluka, Switzerland; Sodium carboxymethyl cellulose (CMC) was purchased from Sinopharm Chemical Reagent Co Ltd. (SCRC), China; anhydrous Calcium chloride $\left(\mathrm{CaCl}_{2}\right.$; molecular weight $\left.110.99 \mathrm{~g} / \mathrm{mol}, 97.0 \%\right)$ was obtained from Penta, Czech Republic; and Sodium carbonate-decahydrate $\left(\mathrm{Na}_{2} \mathrm{CO}_{3}\right.$; molecular weight $\left.286.14 \mathrm{~g} / \mathrm{mol}\right)$, Hydroxyapatite (HA; molecular weight: $502.31 \mathrm{~g} / \mathrm{mol}$ ) were obtained from Sigma Aldrich.

Dulbecco's modified Eagle's medium (DMEM) and Fetal bovine serum (FBS) were obtained from Gibco-Invitrogen (Loughborough, UK). Thiazolyl blue tetrazolium bromide (MTT). Dimethyl sulfoxide (DMSO) and Trypsin were obtained from AppliChem (Darmstadt, Germany). Agar is supplied by Fluka, Switzerland. The antibiotics (Penicillin and Streptomycin) for cell cultures were from Lonza (Verviers, Belgium). Ethylenediaminetetraacetic acid (EDTA), Glutaraldehyde, Ammonium hydroxide, Formaldehyde and all other chemicals of the highest purity commercially available were purchased from local agents and distributors. All sterile plastic ware and syringe filters were from Orange Scientific (Braine-1' Alleud, Belgium). Agarose (low-gelling) was purchased from Sigma-Aldrich. ANNEXINV-GFP-Certified Apoptosis/Necrosis detection kit was used from Enzo Life Sciences (Long Island, NY, USA).

\subsection{Synthesis and Preparation of Homogenous Suspension of $B C$}

BC (holding $99 \% \mathrm{H}_{2} \mathrm{O}$ ) was synthesized in presence of basal synthetic Hestrin-Schramm (HS) nutritive medium ( $\mathrm{pH}$ 7.0) using Gluconacetobacter xylinus CCM $3611^{T}$ (syn. Acetobacter xylinum) at $30{ }^{\circ} \mathrm{C}$ for 15 days. $100 \mathrm{~mL}$ bacteriological culture bottles were inoculated with $5 \mathrm{~mL}$ of H.S. medium containing $96 \times 10^{8}$ cells $/ \mathrm{mL}$ bacteria (bacteria counted at $550 \mathrm{~nm}$ wavelength with Grant-Bio McFarland Densitometer DEN-1B, Grant Instruments Ltd., UK). The freshly prepared BC pellicle is treated with $0.5 \mathrm{~N} \mathrm{NaOH}$ solution and then heated at $80{ }^{\circ} \mathrm{C}$ for $1 \mathrm{~h}$ to remove the possible contaminations from the $\mathrm{BC}$ pellicle. Thereafter, a homogenous suspension of $\mathrm{BC}$ (particle size: $351.03 \mathrm{~nm}$ ) from the obtained $\mathrm{BC}$ mat was prepared by grinding the $\mathrm{BC}$ mat in distilled water.

\subsection{Preparation of Inorganic Calcium Phosphate Filled BC Based Hydrogel Scaffold}

BC based hydrogel scaffolds were first developed by applying the BC (holding 99\% water) with CMC and PVP (Table 1) [49]. Polyethylene glycol (PEG) was also used in all the solutions to reduce 
the risk of tissue damage and other significant cytotoxic effects [50]. Agar used as gelling agent and glycerin used as humectant [49].

Additionally, $\beta$-TCP and HA were applied in the ratio of 20:80 [49,51] in the hydrogel scaffolds to produce the inorganic calcium phosphate filled $B C$ based hydrogel scaffolds. The prepared scaffolds were termed as, "BC-PVP- $\beta$-TCP/HA" and "BC-CMC- $\beta$-TCP/HA" (Figure 5), where, BC-PVP and BC-CMC hydrogel scaffolds were used as base scaffolds/control set [19].

Table 1. Composition of inorganic calcium phosphate filled BC based hydrogel scaffold [48,49].

\begin{tabular}{ccccccccc}
\hline Sample Index & PVP (g) & CMC (g) & BC (g) & PEG (g) & Agar (g) & $\begin{array}{c}\text { Glycerin } \\
(\mathbf{m L})\end{array}$ & $\begin{array}{c}\beta-T C P / H A \\
(\mathbf{g})\end{array}$ & $\begin{array}{c}\text { Water } \\
(\mathbf{m L})\end{array}$ \\
\hline BC-PVP & 0.5 & 0.0 & 0.5 & 1 & 2 & 1 & $0.0 / 0.0$ & 95 \\
BC-CMC & 0.0 & 0.5 & 0.5 & 1 & 2 & 1 & $0.0 / 0.0$ & 95 \\
BC-PVP- $\beta$-TCP /HA & 0.5 & 0.0 & 0.5 & 1 & 2 & 1 & $0.2 / 0.8$ & 94 \\
BC-CMC- $\beta-\mathrm{TCP} / \mathrm{HA}$ & 0.0 & 0.5 & 0.5 & 1 & 2 & 1 & $0.2 / 0.8$ & 94 \\
\hline
\end{tabular}

The BC based hydrogel scaffolds were prepared following the solvent casting method, applying moist heat and pressure. $100 \mathrm{~mL}$ polymer solutions were prepared in $250 \mathrm{~mL}$ sealed glass bottles under $15 \mathrm{lbs}(107 \mathrm{KPa})$ pressure and $120^{\circ} \mathrm{C}$ temperature for $20 \mathrm{~min}$ [6]. Two sets of polymer solutions were prepared; where one set was without inorganic calcium phosphate, and another set was with inorganic calcium phosphate ( $\beta$-TCP/HA). $25 \mathrm{~mL}$ polymer solution from each sealed glass bottles was poured into $75 \mathrm{~mm}$ diameter petri-dishes and allowed to cool at room temperature $\left(22-25^{\circ} \mathrm{C}\right)$. Finally, smooth, round shaped, off white color BC based scaffold without inorganic calcium phosphate ("BC-PVP" and "BC-CMC") were achieved; diameter: $75 \mathrm{~mm}$; thickness: $6.0-6.2 \mathrm{~mm}$ in wet state. The inorganic calcium phosphate filled scaffolds are termed as "BC-PVP- $\beta$-TCP/HA" and "BC-CMC- $\beta$-TCP/HA"; diameter: $75 \mathrm{~mm}$; thickness: $5.5-6 \mathrm{~mm}$ of hydrogel scaffolds were attained.

\subsection{Preparation of Biomineralized Inorganic Calcium Phosphate and Calcium Carbonate $\left(\mathrm{CaCO}_{3}\right)$ Filled BC Based Hydrogel Scaffold}

The calcium phosphate filled BC based hydrogel scaffolds were further bio-mineralized for incorporation of additional $\mathrm{CaCO}_{3}$ for the development of strong bioactive polymeric scaffold material. For achieving that, the in vitro bio-mineralization process was performed following the simple liquid diffusion technique [52]. Two different ionic solutions (i.e., $\mathrm{Na}_{2} \mathrm{CO}_{3}$ and $\mathrm{CaCl}_{2}$ ) were used at fixed concentration ratios $(5.25 / 100 \mathrm{~mL}$ and $7.35 / 100 \mathrm{~mL})$ to prepare inorganic calcium phosphate and $\mathrm{CaCO}_{3}$ filled $\mathrm{BC}$ based hydrogel scaffolds. Research demonstrated that the deposition and accumulation of $\mathrm{CaCO}_{3}$ within the hydrogel scaffold is notable between 60-90 min [29]. Thus, in this study, the bio-mineralization of hydrogel matrix was carried out for $60 \mathrm{~min}$ by keeping the test samples in each ionic solution. The calcium phosphate filled $\mathrm{BC}$ based hydrogel scaffolds were first immersed in $100 \mathrm{~mL}$ solution of $\mathrm{CaCl}_{2} \cdot \mathrm{H}_{2} \mathrm{O}$ for $30 \mathrm{~min}$ and then transferred into $100 \mathrm{~mL}$ of $\mathrm{Na}_{2} \mathrm{CO}_{3}$ solution and kept them for $30 \mathrm{~min}$. In this procedure, calcium phosphate and $\mathrm{CaCO}_{3}$ filled $\mathrm{BC}$ based in vitro bio-mineralized hydrogel scaffold were achieved having diameter: $75 \mathrm{~mm}$; thickness: $4.5-4.9 \mathrm{~mm}$ (in wet state), and as a result, they are finally termed as "BC-PVP- $\beta-\mathrm{TCP} / \mathrm{HA}-\mathrm{CaCO}_{3}$ " and "BC-CMC- $\beta-\mathrm{TCP} / \mathrm{HA}-\mathrm{CaCO}_{3}$ " respectively (Figure 5). 


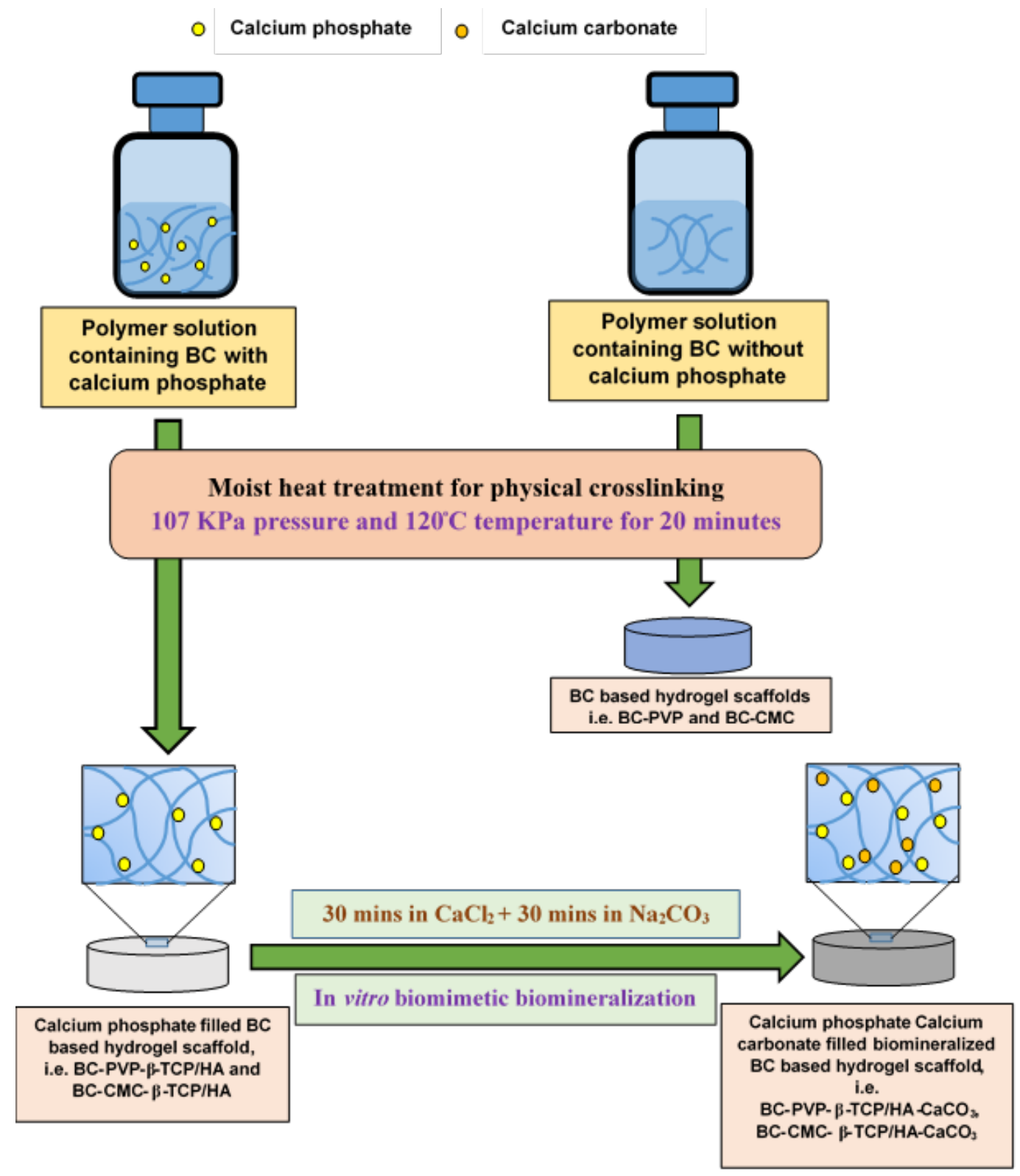

Figure 5. Schematic diagram: preparation of inorganic calcium filled BC based hydrogel scaffolds.

\subsection{Cell cultures}

Human diploid fibroblast; Lep-3 cells from lung of 3-month old human embryo and cell culture established from bone explants of 2-3 months old ICR mice (Bone explant cells, BEC) as it was earlier described [39] were used as model systems in our study. Lep-3 and BEC cells were obtained from the Cell culture collection of the Institute of Experimental Morphology, Pathology and Anthropology with Museum-Bulgarian Academy of Sciences (IEMPAM-BAS).

Both the cultures were grown in DMEM medium supplemented with 10\% fetal bovine serum, $100 \mathrm{U} / \mathrm{mL}$ penicillin and $100 \mu \mathrm{g} / \mathrm{mL}$ streptomycin. The cultures were kept in a humidified incubator (Thermo Scientific, HEPA Class 100, Waltham, MA, USA) at $37{ }^{\circ} \mathrm{C}$ under $5 \% \mathrm{CO}_{2}$ in air. For routine passages, the cells were detached using a mixture of $0.05 \%$ trypsin and $0.02 \%$ EDTA. The cell cultures were passaged 2-3 times per week (1:2 to 1:3 split). The experiments were performed during the exponential phase of cell growth. During investigations performed the BEC cells were on their 44-50th passages. 


\subsection{Evaluation of Cell Viability and Proliferation}

\subsubsection{Sample Preparation}

Circular sections (size: $6 \mathrm{~mm}$ in diameter, $2-3 \mathrm{~mm}$ thickness) of the six freeze dried samples (BC-PVP, BC-CMC, BC-PVP- $\beta$-TCP/HA, BC-CMC- $\beta$-TCP/HA, BC-PVP- $\beta$-TCP $/ \mathrm{HA}-\mathrm{CaCO}_{3}$, $\mathrm{BC}-\mathrm{CMC}-\beta-\mathrm{TCP} / \mathrm{HA}-\mathrm{CaCO}_{3}$ ) were taken for this study. Sections were placed in the 48 -well cell culture plate, treated with $50 \mu \mathrm{L}$ of $96 \%$ ethanol for $40 \mathrm{~min}$ after which the ethanol was removed and dried at $30-32{ }^{\circ} \mathrm{C}$ to complete dryness. Then, the materials were sterilized under the exposure of UV radiation for 80-90 min.

Indirect and direct experiments were performed for evaluating the influence of the materials on cell viability and proliferation

\subsubsection{Indirect Experiments (IDE)}

Each material was placed in bottom of a 48 well cell culture plate on the drop $(20 \mu \mathrm{L})$ of FBS for $30 \mathrm{~min}$ at $30-32{ }^{\circ} \mathrm{C}$ in order to stick the sample to the surface of the well. Thereafter, $1 \mathrm{~mL}$ of DMEM (containing 10\% FBS and antibiotics) was given to the wells (containing sterilized sample sections as well as empty wells that serve as controls) and then placed in the humidified incubator at $37^{\circ} \mathrm{C}$ under $5 \% \mathrm{CO}_{2}$ in air for 3, 5 and 7 days. The cell culture medium (sample extracts and extract control medium) was collected and used in indirect experiments.

For cell viability/proliferation study, the cells (i.e., Lep-3 and BEC) were seeded in 96-well flat-bottomed microplates at a concentration of $1 \times 10^{4}$ cells/well in fresh DMEM medium with $10 \%$ FBS. At the 24th $\mathrm{h}$, the culture medium from each well was removed and changed with $100 \mu \mathrm{L}$ DMEM containing hydrogel scaffolds extract (sample extracts, obtained after 3-, 5and 7-day incubation periods). The percent of viable cells was determined using MTT (3-(4, 5-Dimethylthiazol-2-yl)-2,5-diphenyltetrazolium bromide) test.

MTT test was performed as it was earlier described [33]. Briefly, the cells were incubated for $3 \mathrm{~h}$ with MTT solution ( $0.3 \mathrm{mg}$ MTT in $10 \mathrm{~mL}$ DMEM) at $37{ }^{\circ} \mathrm{C}$ under $5 \% \mathrm{CO}_{2}$ condition. The formed blue MTT formazan was extracted with a mixture of absolute ethanol and DMSO $(1: 1, v / v)$. The quantitative analysis was performed by absorbance measurements in an automated microplate reader (Tecan, Sunrise $^{\mathrm{TM}}$, Grödig, Austria) at 540/620 nm.

\subsubsection{Direct Experiments (DE)}

The cells $\left(5 \times 10^{4}\right.$ cells/well) were seeded directly on the material sample placed on the bottom of a 48-well cell culture plate and incubated for 3,5 and 7 days in $\mathrm{CO}_{2}$ incubator at $37^{\circ} \mathrm{C}$. The number and viability of the cells were determined before seeding using automated cell counter by trypan blue dye exclusion technique (zero time). The cell viability was found to be $>95 \%$ in all experiments performed. At the start of the experiment the cell numbers are equal in all wells / between all different samples, and they are cultured in equal conditions. Cells were grown in wells without materials, served as controls. The effect of the materials on cell viability and proliferation was studied by MTT test as described in Section 4.6.2 with MTT concentration is corresponding to the volume of the plate.

\subsection{Study of DNA Damages}

The presence of single and double stranded DNA damages was assessed by single cell gel electrophoresis (Comet assay) at alkaline $\mathrm{pH}$. Lep-3 cells were seeded in 6-well flat-bottomed microplates at a concentration of $3 \times 10^{5}$ cells/well. At the 24 th hour the culture medium was removed and changed with sample extract media (3-days modified media) and control media prepared as described in Section 4.6.2.

The Lep-3 cells were mixed with $1.4 \%$ of low-gelling agarose (Sigma Type II) and immediately spread onto microscopic slides precoated with $0.5 \%$ normal agarose. Cells were lysed for $1 \mathrm{~h}$ in a lysis solution (1 M NaCl, $50 \mathrm{mM}$ EDTA pH 8, $30 \mathrm{mM} \mathrm{NaOH}, 0.1 \%$ N-lauroylsarcozine; pH 10). After 1-h 
incubation in the denaturing solution ( $30 \mathrm{mM} \mathrm{NaOH}, 10 \mathrm{mM}$ EDTA; $\mathrm{pH}$ 12.6) for DNA unwinding, the slides were electrophoresed for $20 \mathrm{~min}$ at $0.46 \mathrm{~V} / \mathrm{cm}$ in the same denaturing buffer. At the end of the electrophoresis the slides were subsequently dehydrated for $5 \mathrm{~min}$ in $75 \%$ and in $96 \%$ of ethanol. Comets were observed under Leitz epifluorescent microscope (Orthoplan, VARIO ORTHOMAT 2) using a 450-490 nm band-pass filter following staining of microgels with the fluorescent dye SYBR green I (Molecular Probes, Eugene, OR, USA). 1000 randomly chosen objects per each probe and treatment were taken for quantification. Two repetitions of the experiment were done and standard deviations were quantified. In all cases they were very small.

\subsection{Apoptosis/Necrosis Study via Annexin V-FITC}

The ability of the materials to induce cells death was evaluated by APOPTOSIS detection kit, (ANNEXINV-GFP-Certified Apoptosis/Necrosis detection kit, Enzo Life Sciences). Cells were spinned down at $400 \mathrm{~g}$ for $5 \mathrm{~min}$ at room temperature and carefully re-suspended in $1 \mathrm{~mL}$ cold $1 \times \mathrm{PBS}$ $\left(2.68 \mathrm{mM} \mathrm{KCl}, 1.47 \mathrm{mM} \mathrm{KH}_{2} \mathrm{PO}_{4}, 1.37 \mathrm{mM} \mathrm{NaCl}, 8 \mathrm{mM} \mathrm{Na}_{2} \mathrm{HPO}_{4}\right.$ ), pH 7. Spinning down follows at the same conditions and the pellet was re-suspended in $510 \mu \mathrm{L}$ Dual Detection Reagent (500 $\mu \mathrm{L} 1 \times$ binding buffer, $5 \mu \mathrm{L}$ Apoptosis Detection reagent/Annexin V-Enzo Gold; $5 \mu \mathrm{L}$ Necrosis Detection Reagent). Samples were incubated at room temperature for $10 \mathrm{~min}$ at dark and were analysed via cytometry using $488 \mathrm{~nm}$ laser at FL 2 and FL 3 channels for apoptosis and necrosis detection respectively. Results were quantified with FlowJo software. Two repetitions of the experiment were done. Data quantitation included estimation of the percentage of cells undergoing apoptosis and necrosis and the ratio between these percentages in comparison to the control cells is given in PDU (procedure data units).

\subsection{SEM Analysis}

The samples prepared as described in Section 4.6.1. Lep-3 cells $\left(7 \times 10^{5}\right.$ cells/well) were seeded directly on sample materials in a 48-well cell culture plate and left in an incubator (Thermo Scientific) at $37{ }^{\circ} \mathrm{C}, 5 \% \mathrm{CO}_{2}$. After 7 days incubation period, the culture medium was removed and the sample sections were washed with $4 \%$ glutaraldehyde for $1 \mathrm{~h}$ followed by washing with double distilled water. The samples were then subjected to dry by filter system CORNING $431097(0.22 \mu \mathrm{m})$ under low pressure for $2 \mathrm{~h}$ and were left for 2 days at $30-32{ }^{\circ} \mathrm{C}$ for complete drying. Finally, samples were prepared for SEM analysis by a standard procedure and observed under scanning electron microscope (JEOL JSM-5510, Tokyo, Japan) at an accelerating voltage of $10 \mathrm{kV}$.

\subsection{Statistical Analysis}

The data are presented as mean \pm standard error of the mean. Statistical differences between control and treated groups were assessed using one-way analysis of variance (ANOVA) and student's $t$-test followed by suitable post-hoc test by using GraphPad Prism version 5.00 (San Diego, CA, USA) for Windows and MS Office 2010 (Redmond, WA, USA).

\section{Conclusions}

The present work focuses the biocompatibility and biological efficiency of inorganic calcium filled hydrogel scaffold in bone regeneration/bone bioengineering. The comprehensive comparative study with two cell lines indicates the cell biological efficiency of the scaffolds. Lep-3 cell line represents non-specified human fibroblast and mouse bone explant cell (BEC) line represents specified bone cells. The comparative cell viability study (with the extracts of all the six BC based hydrogel scaffolds) and biocompatibility study with two different cell lines indicates that the PVP based hydrogel scaffold can facilitate the growth and proliferation of both types of cell lines. Additionally, the percentage of DNA strand break were found less in PVP based samples than CMC based samples. Furthermore, apoptosis events were not so significantly found in Lep-3 cells with BC-PVP- $\beta$-TCP/HA. Finally, SEM study indicates the efficient adhesion and growth of fibroblast (Lep-3) cells throughout the BC-PVP- $\beta$-TCP/HA hydrogel scaffold surface. Thus, this scaffold exhibits promising osteo-conduction. 
Additionally, the notable cyto-compatibility of this scaffold suggests its putative ability to facilitate the process of bone regeneration. However, further studies are required with different osteogenic cell lines (i.e., osteoblast) and mesenchymal stem cell line to ascertain the efficiency of abovementioned hydrogel scaffold in bone tissue engineering.

Author Contributions: Conceptualization, N.S. and P.S.; Data curation, B.A.-L.; Formal analysis, P.B., R.A., M.G. and G.M.; Funding acquisition, N.S., R.A. and P.S.; Investigation, P.B.; Supervision, N.S.; Writing-original draft, P.B.; Writing-review and editing, N.S., R.A. and M.G.

Funding: This work is mainly supported by the Internal Grant Agency (Project No. IGA/CPS/2017/003 and IGA/CPS/2018/008), Tomas Bata University in Zlin, Czech Republic and Ministry of Education, Youth and Sports of the Czech Republic-NPU Program I (LO1504), National Scientific Fund, Bulgarian Ministry of Education and Science under Grant No. DFNI 502 30, Bulgarian Science Fund (Grant No. DN 11/15) and NATO science for Peace and Security program (Grant No. NATO SPS MYP G5266). Moreover, this work was performed within the framework of COST Action MP1301“New Generation Biomimetic and Customized Implants for Bone Engineering" (www.cost.eu) and COST Action CA15214 "An integrative action for multidisciplinary studies on cellular structural networks".

Conflicts of Interest: The authors declare no conflict of interest.

\section{References}

1. Buenzli, P.R.; Sims, N.A. Quantifying the osteocyte network in the human skeleton. Bone 2015, 75, 144-150. [CrossRef] [PubMed]

2. Kini, U.; Nandeesh, B.N. Physiology of Bone Formation, Remodeling and Metabolism, In Radionuclide and Hybrid Bone Imaging; Springer: Heidelberg, Germany, 2012; pp. 29-57. ISBN 978-3-642-02400-9.

3. International Osteoporosis Foundation (IOF). 2017. Available online: https:/ /www.iofbonehealth.org/factsstatistics (accessed on 30 August 2017).

4. Castilho, M.; Dias, M.; Vorndran, E.; Gbureck, E.; Fernandes, P.; Pires, I.; Gouveia, B.; Armes, H.; Pires, E.; Rodrigues, J. Application of a 3D printed customized Implant for canine cruciate ligament treatment by tibial tuberosity advancement. Biofabrication 2014, 6, 1-13. [CrossRef] [PubMed]

5. Deligkaris, K.; Tadele, T.S.; Olthuis, W. Hydrogel-based devices for biomedical applications. Sens. Actuators B 2010, 147, 765-774. [CrossRef]

6. Roy, N.; Saha, N.; Kitano, T.; Saha, P. Biodegradation of PVP-CMC hydrogel film: A useful food packaging material. Carbohydr. Polym. 2012, 89, 346-353. [CrossRef] [PubMed]

7. Roy, S.G.; De, P. Swelling properties of amino acid containing cross-linked polymeric organogels and their respective poly-electrolytic hydrogels with $\mathrm{pH}$ and salt responsive property. Polymer 2014, 55, 5425-5434. [CrossRef]

8. Saha, N. Morphology, Absorptivity and Viscoelastic Properties of Mineralized PVP-CMC Hydrogel. AIP Conf. Proc. 2013, 1526, 292-300. [CrossRef]

9. Burg, K.J.L.; Porter, S.J.F.; Kellam, J.F. Biomaterial developments for bone tissue engineering. Biomaterials 2000, 21, 2347-2359. [CrossRef]

10. Polo-Corrales, L.; Latorre-Esteves, M.; Ramirez-Vick, J.E. Scaffold design for bone Regeneration. J. Nanosci. Nanotechnol. 2014, 14, 15-56. [CrossRef]

11. Stratton, S.; Shelke, N.B.; Hoshino, K. Bioactive polymeric scaffolds for tissue engineering. Bioact. Mater. 2016, 1, 93-108. [CrossRef]

12. Thavornyutikarn, B.; Chantarapanich, N.; Sitthiseripratip, K. Bone tissue engineering scaffolding: Computer-aided scaffolding techniques. Prog. Biomater. 2014, 3, 61-102. [CrossRef]

13. Walimbe, T.; Panitch, A.; Sivasankar, P.M. A Review of Hyaluronic Acid and Hyaluronic Acid-based Hydrogels for Vocal Fold Tissue Engineering. J. Voice 2017, 31, 416-423. [CrossRef] [PubMed]

14. Ritz, U.; Gerke, R.; Götz, H.; Stein, S.; Rommens, P.M. A New Bone Substitute Developed from 3D-Prints of Polylactide (PLA) Loaded with Collagen I: An In Vitro Study. Int. J. Mol. Sci. 2017, 18, 2569. [CrossRef] [PubMed]

15. Jo, Y.-Y.; Kim, S.-G.; Kwon, K.-J.; Kweon, H.; Chae, W.-S.; Yang, W.-G.; Lee, E.-Y.; Seok, H. Silk Fibroin-Alginate-Hydroxyapatite Composite Particles in Bone Tissue Engineering Applications In Vivo. Int. J. Mol. Sci. 2017, 18, 858. [CrossRef] [PubMed] 
16. Gentile, P.; Chiono, V.; Carmagnola, I.; Hatton, P.V. An Overview of Poly(lactic-co-glycolic) Acid (PLGA)-Based Biomaterials for Bone Tissue Engineering. Int. J. Mol. Sci. 2014, 15, 3640-3659. [CrossRef] [PubMed]

17. Jiang, P.; Ran, J.; Yan, P.; Zheng, L.; Shen, X.; Tong, H. Rational design of a high-strength bone scaffold platform based on in situ hybridization of bacterial cellulose/nano-hydroxyapatite framework and silk fibroin reinforcing phase. J. Biomater. Sci. Polym. Ed. 2018, 29, 107-124. [CrossRef] [PubMed]

18. Keshk, S. Bacterial Cellulose Production and its Industrial Applications, Bacterial Cellulose Production and its Industrial Applications. J. Bioprocess. Biotech. 2014, 4, 1000150. [CrossRef]

19. Shah, R.; Vyroubal, R.; Fei, H.; Saha, N.; Kitano, T.; Saha, P. Preparation of bacterial cellulose based hydrogels and their viscoelastic behavior. AIP Conf. Proc. 2015, 1662. [CrossRef]

20. Ul-Islam, M.; Khan, T.; Kon Park, J. Water holding and release properties of bacterial cellulose obtained by in situ and ex situ modification. Carbohydr. Polym. 2012, 88, 596-603. [CrossRef]

21. Rey, C.; Combes, C.; Drouet, C.; Glimcher, M.J. Bone mineral: Update on chemical composition and structure. Osteoporos. Int. 2009, 20, 1013-1021. [CrossRef] [PubMed]

22. Aquino-Martínez, R.; Artigas, N.; Gámez, B.; Rosa, J.L.; Ventura, F. Extracellular calcium promotes bone formation from bone marrow mesenchymal stem cells by amplifying the effects of BMP-2 on SMAD signaling. PLoS ONE 2017, 12, e0178158. [CrossRef]

23. McCleskey, E.W.; Fox, A.P.; Feldman, D.; Tsien, R.W. Different types of calcium channels. J. Exp. Biol. 1986, 124, 177-190. [PubMed]

24. Dvorak-Ewell, M.M.; Chen, T.H.; Liang, N.; Garvey, C.; Liu, B.; Tu, C.; Chang, W.; Bikle, D.D.; Shoback, D.M. Osteoblast Extracellular $\mathrm{Ca}^{2+}$-Sensing Receptor Regulates Bone Development, Mineralization and Turnover. J. Bone Miner. Res. 2011, 26, 2935-2947. [CrossRef] [PubMed]

25. Dvorak, M.M.; Siddiqua, A.; Ward, D.T. Physiological changes in extracellular calcium concentration directly control osteoblast function in the absence of calciotropic hormones. Proc. Natl. Acad. Sci. USA 2004, 101, 5140-5145. [CrossRef] [PubMed]

26. Ghassemi, T.; Shahroodi, A.; Ebrahimzadeh, M.H.; Mousavian, A.; Movaffagh, J.; Moradi, A. Current concepts in scaffolding for bone tissue engineering. Arch. Bone Jt. Surg. 2018, 6, 2-90.

27. Drzewiecka, K.; Kleczewska, J.; Krasowski, M.; Łapińska, B. Mechanical properties of composite material modified with amorphous calcium phosphate. J. Achiev. Mater. Manuf. Eng. 2016, 74, 22-28. [CrossRef]

28. Muthukumar, T.; Aravinthan, A.; Sharmila, J. Collagen/chitosan porous bone tissue engineering composite scaffold incorporated with Ginseng Compound, K. Carbohydr. Polym 2016, 152, 566-574. [CrossRef] [PubMed]

29. Shah, R.; Saha, N.; Kitano, T.; Saha, P. Preparation of $\mathrm{CaCO}_{3}$-Based Biomineralized Polyvinylpyrrolidone-Carboxymethylcellulose Hydrogels and Their Viscoelastic Behaviour. J. Appl. Polym. Sci. 2014, 40237, 1-9. [CrossRef]

30. Roy, N.; Saha, N.; Kitano, T.; Saha, P. Novel hydrogels of PVP-CMC and their swelling effect on viscoelastic properties. J. Appl. Polym. Sci. 2010, 117, 1703-1710. [CrossRef]

31. Allou, N.B.; Yadav, A.; Pal, M.; Goswamee, R.L. Biocompatible nanocomposite of carboxymethyl cellulose and functionalized carbon-norfloxacin intercalated layered double hydroxides. Carbohydr. Polym. 2018, 186, 282-289. [CrossRef]

32. Saha, N.; Shah, R.; Gupta, P.; Mandal, B.B.; Alexandrova, R.; Sikiric, M.D.; Saha, P. PVP-CMC hydrogel: An excellent bioinspired and biocompatible scaffold for osseointegration. Mater. Sci. Eng. C 2018. [CrossRef]

33. Kim, J.; Cai, Z.; Lee, H.S.; Choi, G.S.; Lee, D.H.; Jo, C. Preparation and characterization of bacterial cellulose/chitosan composite for potential biomedical application. J. Polym. Res. 2011, 18, 739-744. [CrossRef]

34. Saska, S.; Teixeira, L.N.; de Oliveira, P.T.; Gaspar, A.M.M.; Ribeiro, S.J.L.; Messaddeq, Y.; Marchetto, R. Bacterial cellulose-collagen nanocomposite for bone tissue engineering. J. Mater. Chem. 2012, 22, 22102-22112. [CrossRef]

35. Pértile, R.A.N.; Moreira, S.; Gil da Costa, R.M.; Correia, A.; Guãrdao, L.; Gartner, F.; Vilanova, M.; Gama, M. Bacterial Cellulose: Long-Term Biocompatibility Studies. J. Biomater. Sci. Polym. Ed. 2018, 201223, 1339-1354. [CrossRef] [PubMed]

36. Lee, J.H.; Ryu, M.Y.; Baek, H.-R.; Lee, K.M.; Seo, J.-H.; Lee, H.-K. Fabrication and Evaluation of Porous Beta-Tricalcium Phosphate/Hydroxyapatite (60/40) Composite as a Bone Graft Extender Using Rat Calvarial Bone Defect Model. Sci. World J. 2013, 481789, 1-9. [CrossRef] [PubMed] 
37. Kamba, A.S.; Ismail, M.; Ibrahim, T.A.T.; Zakaria, Z.A.B. Biocompatibility of Bio Based Calcium Carbonate Nanocrystals Aragonite Polymorph on NIH 3T3 Fibroblast Cell Line. Afr. J. Tradit. Complement. Altern. Med. 2014, 11, 31-38. [CrossRef] [PubMed]

38. Andonova-Lilova, B.; Alexandrova, R.; Rabadjieva, D.; Tepavitcharova, S. Application of cultured murine cells for initial evaluation of the biocompatibility of $\mathrm{Mg}$ and $\mathrm{Zn}$-modified tri-calcium phosphates. C. R. Acad. Bulg. Sci. 2012, 65, 1099-1104.

39. Martín, L.; Alonso, M.; Girotti, A.; Arias, F.J.; Rodriguez-Cabello, J.C. Synthesis and Characterization of Macroporous Thermosensitive Hydrogels from Recombinant Elastin-Like Polymers. Biomacromolecules 2009, 10, 3015-3022. [CrossRef] [PubMed]

40. Gafter, U.; Malachi, T.; Ori, Y.; Breitbart, H. The role of calcium in human lymphocyte DNA repair ability. J. Lab. Clin. Med. 1997, 130, 33-41. [CrossRef]

41. Buljan, Z.I.; Ribaric, S.P.; Abram, M.; Ivankovic, A.; Spalj, S. In vitro oxidative stress induced by conventional and self-ligating brackets. Angle Orthod. 2012, 82, 340-345. [CrossRef] [PubMed]

42. Guadagno, N.A.; Moriconi, C.; Licursi, V.; D'Acunto, E.; Nisi, P.S.; Carucci, N.; De Jaco, A.; Cacci, E.; Negri, R.; Lupo, G.; Miranda, E. Neuroserpin polymers cause oxidative stress in a neuronal model of the dementia FENIB. Neurobiol. Dis. 2017, 103, 32-44. [CrossRef] [PubMed]

43. Eliaz, N.; Metoki, N. Calcium Phosphate Bioceramics: A Review of Their History, Structure, Properties, Coating Technologies and Biomedical Applications: A Review. Materials 2017, 10, 334. [CrossRef] [PubMed]

44. Voccoli, V.; Tonazzini, I.; Signore, G.; Caleo, M.; Cecchini, M. Role of extracellular calcium and mitochondrial oxygen species in psychosine-induced oligodendrocyte cell death. Cell Death Dis. 2014, 5, 1-10. [CrossRef] [PubMed]

45. McIlwain, D.R.; Berger, T.; Mak, T.W. Review on Caspase Functions in Cell Death and Disease. Cold Spring Harb. Perspect. Biol. 2013, 5, 1-28. [CrossRef] [PubMed]

46. Chang, H.-I.; Wang, Y.I. Cell Responses to Surface and Architecture of Tissue Engineering Scaffolds. In Regenerative Medicine and Tissue Engineering-Cells and Biomaterials; Daniel, E., Ed.; InTech: London, UK, 2011; pp. 569-588. ISBN 978-953-307-6638.

47. Engler, A.J.; Sen, S.; Sweeney, H.L.; Discher, D.E. Matrix elasticity directs stem cell lineage specification. Cell 2006, 126, 677-689. [CrossRef] [PubMed]

48. Basu, P.; Saha, N.; Saha, P. Inorganic calcium filled bacterial cellulose based hydrogel scaffold: A novel biomaterial for bone tissue regeneration. Int. J. Polym. Mater. 2018, in press.

49. Basu, P.; Saha, N.; Bandyopadhyay, S.; Saha, P. Rheological performance of bacterial cellulose based nonmineralized and mineralized hydrogel scaffolds. AIP Conf. Proc. 2017, 1843, 050008. [CrossRef]

50. Alcantar, N.A.; Aydil, E.S.; Israelachvili, J.N. Polyethylene glycol-coated biocompatible surfaces. J. Biomed. Mater. Res. 2000, 51, 343-351. [CrossRef]

51. Struillou, X.; Rakic, M.; Badran, Z.; Macquigneau, L.; Colombeix, C.; Pilet, P.; Verner, C.; Gauthier, O.; Weiss, P.; Soueidan, A. The association of hydrogel and biphasic calcium phosphate in the treatment of dehiscence-type peri-implant defects: An experimental study in dogs. J. Mater. Sci. Mater. Med. 2013, 24, 2749-2760. [CrossRef] [PubMed]

52. Rauch, M.W.; Dressler, M.; Scheel, H.; Opdenbosch, D.V.; Zollfrank, C. Mineralization of Calcium Carbonates in Cellulose Gel Membranes. Eur. J. Inorg. Chem. 2012, 32, 5192-5198. [CrossRef]

(C) 2018 by the authors. Licensee MDPI, Basel, Switzerland. This article is an open access article distributed under the terms and conditions of the Creative Commons Attribution (CC BY) license (http:/ / creativecommons.org/licenses/by/4.0/). 